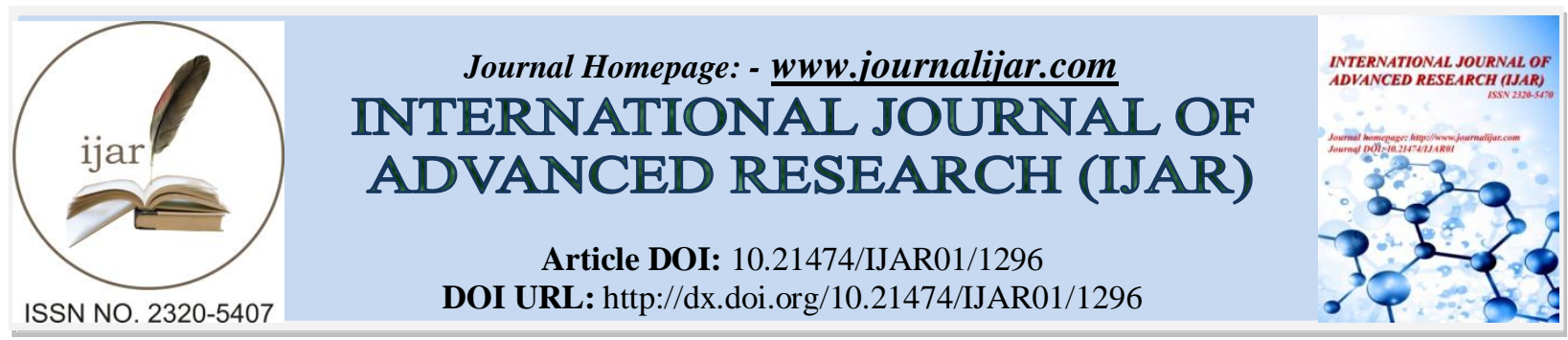

RESEARCH ARTICLE

\title{
EXPLORING ELEMENTS OF SENSATIONALISM, NEGATIVISM, FALSIFICATION AND CODE OF ETHICS IN BREAKING NEWS HYPOTHESES: HOW COLLEGE STUDENTS PERCEIVE NEWS VALENCE FROM SATELLITE TV CHANNELS IN PAKISTAN.
}

\section{Mudassar Hussain Shah ${ }^{1}(\mathrm{PhD})$, Muhammad Yaqoub ${ }^{2}$, Saima Kousar ${ }^{3}$ and Ashok Kumar ${ }^{4}(\mathrm{PhD})$}

1. Department of Communication Studies, University of Sargodha, Sargodha-Pakistan.

2. Department of Media and Communication, GCU, Faisalabad-Pakistan.

3. Department of Mass Communication, Queen Mary College, Lahore-Pakistan.

4. College of International Education, Wuhan University of Technology, Wuhan-P.R. China.

\section{Manuscript Info}

Manuscript History

Received: 18 June 2016

Final Accepted: 22 July 2016

Published: August 2016

Key words:-

Breaking News; Sensationalism;

Negativism; news valence; Private

Television Channels; Pakistan.

\section{Abstract}

To explore the elements of sensationalism, negativism, falsification and code of ethics in the breaking news hypotheses, this study uses the survey research methods by comparing students' perception on Pakistani satellite television channels through well structured questionnaire from 320 respondents. The results indicate that breaking news significantly presented more sensationalism as compare to the other formats of the news. However, respondents consider breaking news to get information contrast to other selected reasons. In general, breaking news considered as negative and society consider its negative effects. At the gender level, the female students perceive significant cognitive and emotional effects from breaking news when news of crimes and terrorist activities presented. To reduce the valence effects of breaking news, the respondents proposed the implementation of code of ethics on breaking news of satellite television channels. The study can be generalized at theoretical and policy level.

Copy Right, IJAR, 2016,. All rights reserved.

\section{Introduction:-}

The history of private TV channels in Pakistan begins from 1990s while it goes through a revolution when Pakistani government permitted licenses and allowed broadcasting of more than 66 private TV channels in year 2000. After the 9/11, Pakistan becomes the front line state on war against terrorism and its naive television news media industry gained significance all across the world. Pakistan has lost more than 49,000 civilian and 15681 armed personals causalities after the 9/11 in Pakistan till 2013 (Raja, 2013). Each and every part of the country was targeted by the terrorists that gave sense of fear to the people of Pakistan. Breaking news as an alarm remains integral part of news production activity. In the need of the news industry, several international media outlet start professional functions with the assistance of their local collaborators. It furnished technological, professional logistical support to local private television industry. Now, the Pakistani satellite television channel industry covering all aspects of life and it is rapidly flourishing. Although, there are several new trends introduced in the industry, despite the fact that Pakistan is considered as most dangerous place on the earth for the practice of Journalism (Cottle, 2016; Cottle et

Corresponding Author:- Mudassar Hussain Shah

Address:- Assistant Professor, Department of Communication Studies, University of Sargodha, 992 
al., 2016; Bhattacharya, 2015; UNESCO, 2013; ). Breaking news is considered as significant new trend in Satellite TV channels.

Sometime, the core values of the news are considerably ignored in the competition. Some studies (Ashraf et al, 2016; Akhtar, 2015; Ali et al, 2013) indicate that private news media is more focusing on breaking news and media's reporting of foreign affairs is limited, superficial and commercial benefits are dominant.

This study is designed to explore the trends of breaking news among private news channels and viewers' perceptions regarding breaking news focusing on sensationalism, negativism, falsification and code of ethics to understand the valance effects on the male and female students of University of Sargodha. A number of private channels are devoted to news and current affairs programs which opened new avenues for the viewers who intend more access to information about important events happening around and abroad.

In order to get attention of the maximum people, private channels started competition with each other especially in providing exclusive and more breaking news. 'Breaking news means as some rare happening' and it needs attention of the viewers while Pakistani private media are presenting every incoming news or any development in news as breaking news. During the breaking news, media channels sensationalize each issue and even disseminate the false and negative news as breaking news. The concept of breaking news has become vogue among various private television news channels in Pakistan. This trend is influencing the viewers' perceptions and their information processing ability regarding different issues. Hence, the authors conducted this research to examine the phenomenon of breaking news among major private TV channels. Most of the people watch news channels to stay updated, such as beware sessions convert them into rather frightened individuals.

\section{Hypotheses:-}

To examine the study statistically, subsequent hypotheses are employed:-

$\mathbf{H}_{\mathbf{1}}$ : It is more likely that breaking news present more sensationalism than other selected formats.

$\mathbf{H}_{2}$ : It is more likely that viewers watch breaking news to get information than other selected reasons.

$\mathbf{H}_{3}$ : It is estimated that most of the stories presented as breaking news are negative.

$\mathbf{H}_{4}$ : It is more likely that effects of breaking news on society are negative.

$\mathbf{H}_{5}$ : It is more likely that female viewers feel more anxiety after watching breaking news of crime as compared to male viewers.

$\mathbf{H}_{\mathbf{6}}$ : It is estimated that news channels don't follow the code of ethics in breaking news.

\section{Development of Breaking News trends in Television:-}

Breaking news is emerging trend among the news media outlets specifically in television news channels. It is observed that private news channels have been changing ironically and establishing new practices. There is a remarkable instance of the impact even supposed breaking news can have on the audience (Orellana-Rodriguez et al., 2016; Cantril, 1952). If immediacy has become the new life-blood of 24 hours news culture than breaking news is its apotheosis (Lewis \& Cushion, 2009). According to Miller (2004) "Breaking news is a story that is unexpected event labeled breaking and unscheduled."Breaking news is a contemporary broadcast journalism technique that alerts the viewers to unexpected, unplanned, and unfolded events (Tuchman, 1978). Breaking news is also known as a special report or news bulletin. In simple words, breaking news is a current issue related information that broadcaster of any mass media feels warrants the interruption of scheduled programming in order to reports its details. Its use is also assigned to the most important story of the movement or an event that is being covered live (cited at: www.study.com). Nowadays, the television news channels see live and breaking news as means to getting viewership. Media personnel consider this presentational style to get attention of the viewers (Tuggle et al., 2002). Live breaking television news reporting has grown significantly since 1990s all over the world. Twenty four hours news channels on cable and technological advancement like helicopter power cams have proliferated in available time and advance equipment as well as financial demands to increase ratings for the sake of advertisings formed an ideal situation for breaking news format (Nelson and Webster, 2016; Eastman \& Ferguson, 1997).

\section{Private Television Industry in Pakistan:-}

The year 2000 considered as the beginning of private television channel industry in Pakistan. The government of Pakistan lifts its embargo over private channels in October, 2002 and brought a Pakistan Electronic Media Ordinance. This opening up motivated several news and media outlets to setup TV channels in Pakistan. At the moment, there are hundreds of local and International TV media outlets are working in Pakistan. The dominant 
content produce in TV channels is news. The concept of 24/7 in private channel industry in Pakistan brought revolution in the industry but it significantly affect the news values. There were many new concepts emerged in news specially breaking news. War against terrorism fueled the news industry, the turmoil situation of the region and continuous devastated situation of peace in the country create significant impact on news valence. Sensationalism and race for first breaking news among industry breach the established norms of the broadcast journalism.

\section{Breaking news as source of Information and creates valence effect:-}

Television has changed the way of getting information. A number of studies reveal that television has become an important part of our lives so it has revolutionized each and every thing over the world (Spingel, 1992; Biocca, 1988; Johnson \& Davey, 1997; Tuggle \& Huffman, 2001). More than (53\%) American use television and trust on television (Jamieson \& Campbell, 2001). Another study's finding of survey noted that many people view news channels to catch up with the breaking news (Associated Press, 2008).

News presented on news channels is mostly negative and emotional arousing. Findings of the study reveal that three most popular U.S. TV stations (ABC, NBC, and CBS) present considerably immense shocking news information as compare to positive news. Majority of the news (47\%) which was covered by these channels attributed as bad news (Stone \& Crusin, 1984). In his findings, Johnson (1996) stated that all news broadcast more news about violence, suffering and conflict. National news broadcasts devoted extra time on warfare and dispute while local news stories presented regularly on crime and tragedy. Findings of the Schster et al. (2001) research reveals that viewers negatively affected by news alerts. Tuggle et al. (2002) consider "Television breaking news as black holes." According to him breaking news trend unplanned started to give live coverage of an event/incident.

Other studies (Dixit, 2016; Brandtzaeg et al, 2016; Klevin, 2003) indicates viewers feel insecure after watching breaking news.

\section{Impact on Heavy viewers and light viewers:-}

Heavy viewers of television news alerts feel more scared (Wilson et al, 2005).

Findings of a study demonstrate that news plays a significant role in increasing the stress level of masses more than any other formats (McIntyre, 2016; Ahern et al, 2004; Watson, 2005). Miller \& Glenn (2007) say that a story becomes more important which is labeled "Breaking". The results of research reveal that female have to face higher level of depression and anxiety as compared to male (Ben-Zur \& Zeidner, 2012). Media outlets failed to deliver quality information to the viewers with social and moral responsibility because of competition among news channels for breaking news first (Brown \& Roemer, 2016; Dhamrah, 2012).

\section{Methodology:-}

The current study comprised primary data which is fresh, original and first hand in character. A descriptive survey research method is employed using self-structured questionnaires (based on 13 closed ended questions while one open ended question) to examine the public perception about the breaking news trends in private channels. Convince sampling technique is employed to access and select the appropriate sample. The universe of this study is consisted on all male and female who work or study in University of Sargodha while sample size $(n=320)$ are drawn from both male and female (160 male and 160 female). Reliability of instrument (questionnaire) shows .830 (Cronbach's Alpha) on 46 items. For all the items, responses are measured on a 3-point Likert scale ranging from 1 (very frequently) to 3 (never). 


\section{Results and Data Analysis:-}

The Table 1 provides the percentage of the respondents both male and female regarding the viewers' interest in breaking news of private TV channels i.e. Geo News, Express News, ARY News, Geo Teez and Dunia News.

\begin{tabular}{|l|c|c|c|c|c|c|}
\hline Table 1:- Viewers' interest in breaking news of private TV Channels. \\
\hline \multirow{2}{*}{ TV Channels } & \multicolumn{7}{|c|}{ Male } & \multicolumn{3}{c|}{ Gender } \\
\cline { 2 - 7 } & Very frequently & Sometimes & Never & Very frequently & Sometimes & Never \\
\hline Geo News & 27.81 & 13.75 & 8.45 & 20.31 & 12.18 & 17.5 \\
\hline Express New & 42.81 & 3.45 & 3.75 & 36.25 & 10.62 & 3.12 \\
\hline ARY News & 24.06 & 15.62 & 10.31 & 15.93 & 20.02 & 14.06 \\
\hline Geo Teez & 14.68 & 13.15 & 22.18 & 6.25 & 12.81 & 30.93 \\
\hline Dunia News & 30.62 & 8.12 & 11.25 & 22.18 & 14.4 & 13.43 \\
\hline Values Showing (\%) & & & & & $n=320$ \\
\hline
\end{tabular}

Gender wise analysis depicts that male viewers (42.81\%) take interest in watching breaking news of Express news more frequently than female $(36.25 \%)$. Further, $30.62 \%, 27.81 \%, 24.06 \%$ and $14.68 \%$ male very frequently view respectively Dunia News, Geo News, ARY News and Geo Teez as compared to female $(22.18 \%, 20.31 \%, 15.99 \%$ and $6.25 \%)$. The Table 2 portrays that majority of the male respondents $(43.12 \%)$ perceive the political based contents that are very frequently presenting as a breaking news as compared to female (35.95\%). Moreover, among the female respondents majority (39.70\%) considered crimes are very frequently presented as breaking news comparatively other contents.

\begin{tabular}{|l|c|c|c|c|c|c|}
\hline \multicolumn{7}{|c|}{ Table 2:- Frequency of presenting issues as breaking news } \\
\hline \multirow{2}{*}{ Contents } & \multicolumn{7}{|c|}{ Male } & \multicolumn{3}{c|}{ Gender } \\
\cline { 2 - 7 } & Very frequently & Sometimes & Never & Very frequently & Sometimes & Never \\
\hline Crimes & 26.81 & 20.37 & 2.81 & 39.70 & 6.25 & 4.06 \\
\hline Sports & 30 & 12.81 & 7.20 & 8.12 & 23.12 & 18.75 \\
\hline Politics & 43.12 & 3.12 & 3.75 & 35.95 & 8.75 & 5.31 \\
\hline Celebrity & 29.68 & 11.87 & 8.43 & 20 & 23.12 & 6.9 \\
\hline Values Showing (\%) & & & & & $n=320$ \\
\hline
\end{tabular}

The Table 3 shows gender wise percentage regarding sensationalism in different formats. Majority of the male $(42.32 \%)$ consider very frequently sensationalism in breaking news format while most of the female $(36.93 \%)$ believe that crime shows present more sensationalism than other formats e.g. breaking news, infotainment, and current affairs.

Overall, findings reveal that breaking news present more sensationalism than other selected formats. Thus, $\mathrm{H}_{1}$ (alternative hypothesis) will be accepted while null hypothesis will be rejected.

\begin{tabular}{|l|c|c|c|c|c|c|}
\hline \multicolumn{7}{|l|}{ Table 3:- Frequency of sensationalism in different formats. } \\
\hline \multirow{2}{*}{ Formats } & \multicolumn{7}{|c|}{ Male } & \multicolumn{3}{c|}{ Gender } \\
\cline { 2 - 8 } & Very frequently & Sometimes & Never & Very frequently & Sometimes & Never \\
\hline Breaking news & 40.32 & 7.18 & 2.5 & 35.62 & 9.70 & 4.68 \\
\hline Infotainment & 16.87 & 20.95 & 12.18 & 10.93 & 19.37 & 19.70 \\
\hline Crime Shows & 34.68 & 10.93 & 4.37 & 36.93 & 7.45 & 5.64 \\
\hline Current Affairs & 28.45 & 15.31 & 6.25 & 14.06 & 22.81 & 13.12 \\
\hline Values Showing (\%) & & & & & $n=320$ \\
\hline
\end{tabular}

The Table 4 depicts that majority of the both male (42.4\%) and female (38.8\%) participants watch the breaking news for awareness and information. In addition, $32.2 \%$ male view the breaking news to entertain himself or herself while $28.1 \%$ female sometimes watch breaking news for entertainment. 
Overall, findings reveal that viewers watch breaking news to get information than any other reason. Thus, $\mathrm{H}_{2}$ (alternative hypothesis) will be accepted will while $\mathrm{H}_{0}$ will be rejected.

\begin{tabular}{|c|c|c|c|c|c|c|}
\hline \multirow{3}{*}{ Reasons } & \multicolumn{6}{|c|}{ Gender } \\
\hline & \multicolumn{3}{|c|}{ Male } & \multicolumn{3}{|c|}{ Female } \\
\hline & Very frequently & Sometimes & Never & Very frequently & Sometimes & Never \\
\hline Information & 42.4 & 5.05 & 2.5 & 38.8 & 9.45 & 1.8 \\
\hline Entertainment & 32.2 & 12.5 & 5.3 & 7.8 & 28.10 & 14.1 \\
\hline Sensationalism & 15.0 & 24.0 & 11 & 4.7 & 11.50 & 33.8 \\
\hline To kill time & 12.8 & 5.3 & 31.9 & 3 & 3.80 & 42.5 \\
\hline \multicolumn{2}{|c|}{ Values Showing (\%) } & & & & & $n=320$ \\
\hline
\end{tabular}

The Table 5 demonstrates the use of unknown sources in breaking news. Most of the female $(36.25 \%, 29.37 \%)$ and male $(35.31 \%, 31.56 \%)$ deem that Geo News and Geo Teez channels very frequently use unknown sources in breaking news as compared to other news channels.

\begin{tabular}{|l|c|c|c|c|c|c|}
\hline Table 5:- Frequency of unknown sources using in breaking news. \\
\hline & \multicolumn{7}{c|}{ Gender } \\
\hline \multirow{2}{*}{ TV Channels } & \multicolumn{7}{c|}{ Male } & \multicolumn{3}{c|}{ Female } \\
\cline { 2 - 7 } & Very frequently & Sometimes & Never & Very frequently & Sometimes & Never \\
\hline Geo News & 35.31 & 9.38 & 5.31 & 36.25 & 8.75 & 5 \\
\hline Express New & 18.12 & 20.93 & 10.93 & 22.19 & 22.5 & 5.33 \\
\hline ARY News & 18.44 & 22.5 & 9.06 & 19.69 & 22.5 & 7.81 \\
\hline Geo Teez & 31.56 & 11.56 & 6.9 & 29.37 & 13.43 & 7.18 \\
\hline Dunia News & 19.37 & 20.33 & 10.31 & 17.5 & 25.62 & 6.87 \\
\hline Values Showing (\%) & & & & & $n=320$ \\
\hline
\end{tabular}

It is commonly believed that mostly news channels present commonly negative stories as breaking news. The gender wise analysis of the study in Table 6 reveals that there is no difference between male and female. Overall findings state that majority of the respondents both male and female think very frequently that breaking news are based on negative news.

The Chi-Square results are as subsequent:-

"From these findings, alternative hypothesis $\left(\mathrm{H}_{3}\right)$ will be accepted while $\mathrm{H}_{0}$ will be rejected..., $\mathrm{X}^{2}=253.250$, df $=4$, $\mathrm{p}=.000 . "$

Table 6:- Frequency of breaking news on negative stories.

\begin{tabular}{|c|c|c|c|c|c|}
\hline \multicolumn{7}{|c|}{ Gender } \\
\hline Male & \multicolumn{3}{c|}{ Female } \\
\hline Vory frequently & Sometimes & Never & Very frequently & Sometimes & Never \\
\hline 32.81 & 14.37 & 2.81 & 33.91 & 13.60 & 2.5 \\
\hline Values Showing (\%) & & & & & $n=320$ \\
\hline
\end{tabular}

\begin{tabular}{|l|l|}
\hline \multicolumn{2}{|l|}{ Test Statistics } \\
\hline & Negative stories \\
\hline Chi-Square & $253.250^{\mathrm{a}}$ \\
\hline Df & 4 \\
\hline Asymp. Sig. & .000 \\
\hline a. 0 cells $(0.0 \%)$ have expected frequencies less than 5. The minimum expected cell frequency is 64.0. \\
\hline
\end{tabular}


The Table 7 presents that effect of breaking news significantly negative. Comparative analysis reveals that majority of the respondents both male $(29.1 \%)$ and female $(34.1 \%)$ very frequently believe that breaking news has negative effects.

The Chi-Square results are as subsequent:-

"From these findings, alternative hypothesis $\left(\mathrm{H}_{4}\right)$ will be accepted while $\mathrm{H}_{0}$ will be rejected..., $\mathrm{X}^{2}=172.500, \mathrm{df}=4$, $\mathrm{p}=.000 . "$

Table 7:- Frequency of negative effects.

\begin{tabular}{|c|c|c|c|c|c|}
\hline \multicolumn{7}{|c|}{ Gender } \\
\hline Male & \multicolumn{3}{c|}{ Female } \\
\hline Very often & Sometimes & Never & Very often & Sometimes & Never \\
\hline 29.1 & 16.85 & 4.1 & 34.1 & 12.45 & 3.4 \\
\hline Values Showing (\%) & & & & $n=320$ \\
\hline
\end{tabular}

\begin{tabular}{|c|c|}
\hline \multicolumn{2}{|l|}{ Test Statistics } \\
\hline & Negative effects \\
\hline Chi-Square & $172.500^{\mathrm{a}}$ \\
\hline Df & 4 \\
\hline Asymp. Sig. & .000 \\
\hline
\end{tabular}

The Table 8 illustrates that female (44.1\%) feel very often anxiety than male viewers (29.1).

The Chi-Square results are as subsequent:-

"From these findings, alternative hypothesis $\left(\mathrm{H}_{5}\right)$ will be accepted while $\mathrm{H}_{0}$ will be rejected.., $\mathrm{X}^{2}=15.697, \mathrm{df}=4$, $\mathrm{p}=.003 . "$

\begin{tabular}{|c|c|c|c|c|c|}
\hline Table 8:- Frequency of feeling anxiety after watching breaking news \\
\hline \multicolumn{6}{|c|}{ Gender } \\
\hline \multicolumn{7}{|c|}{ Male } & Never & Very often & Sometimes & Never \\
\hline Very often & Sometimes & 2.8 & 44.1 & 3.4 & $n=320$ \\
\hline 29.1 & 18.1 & & & & $n$ \\
\hline Values Showing (\%) & & &
\end{tabular}

\begin{tabular}{|l|l|l|l|}
\hline Chi-Square Tests \\
\hline & Value & Df & Asymp. Sig. (2-sided) \\
\hline Pearson Chi-Square & $15.697^{\text {a }}$ & 4 & .003 \\
\hline Likelihood Ratio & 16.013 & 4 & .003 \\
\hline Linear-by-Linear Association & 7.740 & 1 & .005 \\
\hline N of Valid Cases & 320 & & \\
\hline a. 2 cells (20.0\%) have expected count less than 5. The minimum expected count is 1.50. \\
\hline
\end{tabular}

Gender wise analysis in Table 9 points up that female $(40.3 \%)$ feel very much insecure than the male viewers $(32.2 \%)$.

\begin{tabular}{|c|c|c|c|c|c|}
\hline \multicolumn{6}{|c|}{ Gender } \\
\hline \multicolumn{3}{|c|}{ Male } & \multicolumn{3}{|c|}{ Female } \\
\hline Very much & Sometimes & Never & Very much & Sometimes & Never \\
\hline 32.2 & 12.2 & 5.6 & 40.3 & 5.0 & 4.7 \\
\hline Values Showing (\%) & & & & & $n=320$ \\
\hline
\end{tabular}

The Table 10 depicts that majority of male viewers (40\%, 38.1\%) believe respectively Geo News and Dunia News very frequently present breaking news on petty issues as compared to female viewers $(36.6 \%$ and $28.4 \%)$. The Table 11 reveals somewhat difference that male respondent $(31.3 \%)$ believe news channels violate the code of ethics in 
breaking news as compared to female respondents (29.4\%). Overall both male and female respondents state that news media very often $(60.7 \%)$ violating the code of ethics presenting the breaking news.

\begin{tabular}{|l|c|c|c|c|c|c|}
\hline Table 10:- Frequency of breaking news on petty issues. \\
\hline & \multicolumn{7}{|c|}{ Male } & \multicolumn{3}{c|}{ Gender } \\
\hline \multirow{2}{*}{ TV Channels } & \multicolumn{7}{|c|}{ Sometimes } & Never & Very frequently & Sometimes & Never \\
\cline { 2 - 7 } & Very frequently & 8.35 & 1.6 & 36.6 & 11.25 & 2.2 \\
\hline Geo News & 40.0 & 14.4 & 10.0 & 29.4 & 17.2 & 3.4 \\
\hline Express New & 25.6 & 14.4 & 6.9 & 28.4 & 18.4 & 3.1 \\
\hline ARY News & 28.8 & 9.7 & 5.9 & 34.7 & 13.4 & 1.9 \\
\hline Geo Teez & 34.4 & 8.45 & 3.4 & 28.4 & 19.15 & 2.5 \\
\hline Dunia News & 38.1 & & & & & $n=320$ \\
\hline \multicolumn{2}{|l|}{ Values Showing (\%) } & & & & & \\
\hline
\end{tabular}

The Chi-Square results are as subsequent:-

"From these findings, alternative hypothesis $\left(\mathrm{H}_{3}\right)$ will be accepted while $\mathrm{H}_{0}$ will be rejected..., $\mathrm{X}^{2}=229.531$, $\mathrm{df}=4$, $\mathrm{p}=.000 . "$

\begin{tabular}{|c|c|c|c|c|c|}
\hline \multicolumn{7}{|c|}{ Table 11:- Violation of code of ethics in breaking news. } \\
\hline \multicolumn{7}{|c|}{ Gale } \\
\hline Very frequently & Sometimes & Never & Very frequently & Sometimes & Never \\
\hline 31.3 & 13.1 & 5.6 & 29.4 & 17.2 & 3.4 \\
\hline Values Showing (\%) & & & & & $n=320$ \\
\hline
\end{tabular}

\begin{tabular}{|l|l|}
\hline Test Statistics & Code of Ethics \\
\hline Chi-Square & $229.531^{\text {a }}$ \\
\hline Df & 4 \\
\hline Asymp. Sig. & $\mathbf{. 0 0 0}$ \\
\hline a. 0 cells $(0.0 \%)$ have expected frequencies less than 5. The minimum expected cell frequency are 64.0. \\
\hline
\end{tabular}

\section{Discussion:-}

From this analysis of breaking news trends in Pakistani private news channels, findings of current study leads to draw inferences that male viewers (42.81\%) take interest in watching breaking news of Express news more frequently than female $(36.25 \%)$. This study reveals that majority of the male respondents $(43.12 \%)$ perceive the political based contents that are very frequently presenting as a breaking news while among the female respondents majority (39.70\%) considered crimes are very frequently presented as breaking news comparatively other contents. Majority of the male (42.32\%) consider very frequently sensationalism in breaking news format while most of the female $(36.93 \%)$ believe that crime shows present more sensationalism than other formats e.g. breaking news, infotainment, and current affairs. Overall, findings reveal that viewers watch breaking news to get information than any other reason. Daredia et al. (2013) research findings also support as $68.3 \%$ respondents use TV news as the source of getting information. The majority of the respondents both male and female think very frequently breaking news is based on negative news. Comparative analysis reveals that majority of the respondents both male (29.1\%) and female $(34.1 \%)$ very frequently believe that breaking news has negative effects as compare to positive effects. The results of the study reveal that female $(44.1 \%)$ feel very often anxiety than male viewers $(29.1 \%)$. Overall, the findings of Harrell (2000) state that individuals who watch negative news stories considerably feel anxiety. Gender wise analysis points up that female (40.3\%) feel very much insecure than the male viewers $(32.2 \%)$. Research findings (Brown and Roemer, 2016; Klevin, 2003) indicate same that viewers feel insecure after watching news.

The findings conclude that majority of male viewers $(40 \%, 38.1 \%)$ believe respectively Geo News and Dunia News very frequently present breaking news on petty issues as compared to female viewers (36.6\% and $28.4 \%$ ). Overall both male and female respondents state that news media very often (60.7\%) violating the code of ethics presenting 
the breaking news. Uncontrolled desire for news joined with the competitive breaking news format presents a reporting style that violates media ethics (Brandtzaeg et al, 2016; Cottle, 2016; Gajendra \& Tejaswi, 2013).

\section{Conclusion:-}

After the interpretation of the above findings and analysis of current research it notes that effective check and balance system is required to stop the hunger of supremacy and individual projection in media. News channels must ensure the news values to make sure the accuracy of news. Frequently presentation of immature and exaggerated information should be stopped. News media should follow the social responsibility doctrine. Media should focus on and highlight the major issues of the society.

\section{Implication for Future Research:-}

Other researchers can conduct the studies in following areas; Impacts of breaking news of radio or social media. Comparison between Pakistan Television news and private news channels regarding breaking news phenomenon. Both contents analysis and survey research can be applied to compare the findings of news coverage in shape of breaking and public perception i.e. Impact of breaking news on journalistic values of news, Impact of thrilling and exciting background music during breaking news.

\section{Acknowledgements}

The authors pay sincere acknowledgements to the Prof. Dr. Muhammad Nawaz Mehsud, Dean Faculty of Arts and Law, University of Sargodha for his research guidance and valued inputs.

\section{References:-}

1. Ahern, J. Galea, S., Resnick, H., \& Vlahov, D. (2004). Television images and probable posttraumatic stress disorder after September 11: The role of background characteristics, event exposures and prevalent panic. Journal of Nervous and Mental Diseases, 192 (3), 217-226.

2. Akhtar, N. (2015). Composite Dialogues between India and Pakistan: Challenges and Impediments. International Journal on World Peace, 32(3), 49-62.

3. Ali, Z., Jan, M. \& Bukhari, S. Q. (2013). Role of Electronic Media in Changing Value System in Pakistan. The International Asian Research Journal, 1(1), 59-65.

4. Ashraf, S. I., Soherwordi, S. H. S., \& Javed, T. (2016). Herman and Chomsky's Propaganda Model: Its Application on Electronic Media and Journalists in Pakistan. Journal of Political Studies, 23(1), 273.

5. Associated Press, (2008). A new Model for news studying the deep structure of young-adult news consumption. A research report from the Associated Press and the Context-Based Research Group. Retrieved on November 25, 2014 from http://www.ap.org/newsmodel.pdf

6. Ben-Zur, H. \& Zeidner, M. (2012). Gender differences in loss of psychological resources following experimentally-induced vicarious stress. Anxiety, stress \& Coping, 25(4), 457-475.

7. Bhattacharya, S. (2015). Violence: A Bane for Pakistani Media. Journal of the International Relations and Affairs Group, 5 (2), 228-248.

8. Biocca, F. A. (1988). Opposing conceptions of the audience: the active and passive hemispheres of mass communication theory. Communication Arbook, 11(648), 51-80.

9. Brandtzaeg, P. B., Lüders, M., Spangenberg, J., Rath-Wiggins, L., \& Følstad, A. (2016). Emerging journalistic verification practices concerning social media. Journalism Practice, 10(3), 323-342.

10. Brown, C., \& Roemer, R. C. (2016). Local Television News in Salinas, California Defining and Informing a Latino Community with Excessive Crime News Coverage. Electronic News, 10(1), 3-23.

11. Cantril, H. (1952). The invasion from the Mars: a study in the psychology of panic. Princeton: Princeton University Press.

12. Cottle, S. (2016). Keeping Safe (r) in Unruly, Uncivil Places: Journalist Voices in a Changing Communications Environment. In Reporting Dangerously (pp. 145-167). Palgrave Macmillan UK.

13. Cottle, S., Sambrook, R., \& Mosdell, N. (2016). Reporting Dangerously: Journalist Killings, Intimidation and Security. Springer.

14. Daredia, K., Zehra, A., Rasheed, S. (2013). Psychological effects of viewing news channels among adult population of Karachi. Pakistan Journal of Medicine and Dentistry, 2(1), 24-32.

15. Dhamrah. H. M. (2012). Violation of Media Ethics. Roshni.com. Retrieved. 
16. Dixit, P. (2016). Securitization and Terroristization: Analyzing States' Usage of the Rhetoric of Terrorism. In State Terror, State Violence (pp. 31-50). Springer Fachmedien Wiesbaden.

17. Eastman, S. \& Ferguson, D. (1997). Broadcast/cable programming. Belmont, CA: Wadsworth Publishing Company.

18. Gajendra, S. C. \& Tejaswi, R. (2013)

19. Harrell, J. P. (2000). Affective responses to television newscasts: have you heard the news? Doctoral dissertation, Western Michigan University, Dissertation Abstracts International, 61(5B), 27-62.

20. Jamieson, K. H. \& Campbell, K. K. (2001). The interplay of influence $\left(5^{\text {th }}\right.$ Ed.). New York: Wadswort.

21. Johnson, R. N. (1996). Bad news revisited: The portrayal of violence, conflict, and suffering on television news. Peace and Conflict. Journal of peace Psychology, 88(1), 85-91.

22. Johnson. W. M. \& Davey, G. C. L. (1997). The Psychological impact of negative TV news bulletins: the catastrophizing of personal worries. British Journal of Psychology, 88(1), 85-91.

23. Klevin, D. R. (2003). Audience reactions to local TV news. American Behavioral Scientist, 46 (12), pp. 16611672 .

24. Lewis, J. \& Cushion, S. (2009). The first to be first. Journalism Practice, 3(3), 304-318.

25. McIntyre, K. (2016). What Makes "Good" News Newsworthy? Communication Research Reports, 33(3), 223230.

26. Miller, A. L. (2004). Live, Breaking \& Emotional: Processing television news information. Paper presented at annual meeting of the International Communication Association, New Orleans Sheraton. Retrieved on October 25, 2014 from http://www.allacademic.com

27. Nelson, J. L., \& Webster, J. G. (2016). Audience Currencies in the Age of Big Data. International Journal on Media Management, 18 (1), 1-16.

28. Orellana-Rodriguez, C., Greene, D., \& Keane, M. T. (2016, May). Spreading the news: how can journalists gain more engagement for their tweets? In Proceedings of the 8th ACM Conference on Web Science (pp. 107-116). ACM.

29. Schster, M. A. Stein, B. D., Jaycox, L. H. Collins, R. L., Marshall, G. N., Elliott, M. N., \& Berry, S. H. (2001). A national survey of stress reactions after the September 11, 2001, terrorist attacks. New England Journal of Medicine, 345(20), pp.1507-1512.

30. Spingel, L. (1992). Make room for TV. Chicago: University of Chicago Press, p.100.

31. Stone, G. C. \& Crusin, E. (1984). Network TV as the bad news bearer. Journalism Quarterly, 61 (3), 517-523.

32. Tuchman, G. (1978). Making news. A study in the construction of reality. New York: Free Press. P.59.

33. Tuggle, C. Huffman, S. \& Rosengard, D. (2002). Live news reporting: How a young demographic views it. Paper presented to the annual meeting of the Association for Education in Journalism and Mass Communication, Miami, FL. Retrieved on December 15, 2014 from http://www.allacademic.com

34. Tuggle. C. A. \& Huffman, S. (2001). Live reporting in television news. Breaking news or black holes? Journal of Broadcasting \& Electronic Media, 45 (2), 335-344.

35. Watson, W. J. (2005). Cognitive effects of breaking news: Establishing a media frame to test audience primes. A dissertation submitted to the College of Communication \& Information of Kent State University. Retrieved on December 20, 2014 from https://etd.ohiolink.edu/

36. Wilson, B. J. Martins N. \& Marske, A. L. (2005). Children's and parents' fright reactions to kidnapping stories in the news. Communication Monographs, 72(1), 46-70. 